УДК 636.2+082.453.5:543.02.062

Г. В. Максим’юк, 3. Д. Воробець, В. М. Максим’юк

Львівський національний медичний університет ім. Данила Галищьького

Інститут сільського господарства Карпатського регіону НААН Украӥни

\title{
ЗВ'ЯЗОК КОНЦЕНТРАЦІЙ СПЕРМАТОЗОЇДІВ ТА ІОНІВ СОЛЕЙ ЛУЖНИХ МЕТАЛІВ У СПЕРМІ
}

Дестабілізація низької, середньої та високої концентрацій $K^{+}$спермальної плазми, сперматозоїдів, сперми пов'язана з гіпо- та гіперфункцій генеративних тканин статевих органів. Контроверзні коцентрації $\mathrm{K}^{+}$та константні співвідношення $\mathrm{Ca}^{2+}, \mathrm{K}^{+}, \mathrm{Na}^{+}$за нормофункцій і дестабілізація їх вмісту та співвідношень у спермальній плазмі, сперматозоїдах за гіпо- та гіперфункції вказують на те, що особливості гомеостазу іонів у спермі запрограмовані на генному рівні.

\section{А. В. Максимьюк, З. Д. Воробец, В. М. Максимьюк}

\author{
Львовский национальный медицинский университет им. Данила Галиикого \\ Институт сельского хозяйства Карпатского региона НААН Украӥни
}

\section{СВЯЗЬ КОНЦЕНТРАЦИЙ СПЕРМАТОЗОИДОВ И ИОНОВ СОЛЕЙ ЩЕЛОЧНЫХ МЕТАЛЛОВ В СПЕРМЕ}

Дестабилизация низкой, средней и высокой концентраций $\kappa^{+}$спермальной плазмы, сперматозоидов, спермы связана с гипо- и гиперфункцией генеративных тканей половых органов. Контроверзные концентрации $\mathrm{K}^{+}$и константные соотношения $\mathrm{Ca}^{2+}, \mathrm{K}^{+}, \mathrm{Na}^{+}$при нормофункции и дестабилизация их содержания и соотношений в спермальной плазме и сперматозоидах при гипо- и гиперфункции указывают на то, что особенности гомеостаза ионов в сперме запрограммированы на генетическом уровне.

H. V. Maksymjuk, Z. D. Vorobets, V. M. Maksymjuk

Danylo Galician Lviv National Medical University

Institute of Agriculture of the Carpathian Region, NAAS of Ukraine

\section{RELATIONSHIP BETWEEN THE CONCENTRATION OF SPERMATOZOA AND ALKALI IONS IN THE SEMEN}

It was found that destabilization of the low, medium and high concentrations of $\boldsymbol{K}^{+}$in seminal fluid, spermatozoa and sperm is related to the hypo- and hyperfunctions of genitals' generative tissues. The unmatched $\mathrm{K}^{+}$concentrations and constant ratios of $\mathrm{Ca}_{2}^{+}, \mathrm{K}^{+}$and $\mathrm{Na}^{+}$under presence of normofunction and destabilization of their contents and ratios in seminal plasma and spermatozoa under hypo- and hyperfunction indicate that the features of ion homeostasis in sperm are programmed at the genetic level.

\section{Вступ}

Загальноприйняті методи діагностики неплідності не завжди вказують на причину зниження життєздатності та біологічної повноцінності сперматозоїдів. У цьому плані відомо, що внутрішньоклітинний гомеостаз $\mathrm{Ca}^{2+}, \mathrm{K}^{+}$та $\mathrm{Na}^{+}$, який лежить в основі підтримання життєдіяльності клітин, досягається завдяки складній і координованій системі їх активного та пасивного транспорту. Виявлена $[1-3 ; 5 ; 8 ; 9 ; 11 ; 12]$ контро- 
верзність рівнів - низької (НКК), середньої (СКК) та високої (ВКК) концентрації $K^{+}$у спермі потребує досліджень, які у близькому майбутньому дозволять з'ясувати дійсні (реально існуючі) причини іï появи [10; 13-15]. Тому в еякулятах високої та низької якості, з метою обгрунтування можливості впливу функціонального стану (гіпо-, нормо- та гіпер-) генеративних тканин органів статевої системи на гомеостаз $\mathrm{Ca}^{2+}, \mathrm{K}^{+}$та $\mathrm{Na}^{+}$спермальної плазми, сперматозоїдів та між ними, вивчали особливості їх концентрації, розподілу та співвідношень.

\section{Матеріал і методи досліджень}

Отримані від фізіологічно здорових бугаїв різних порід, віком 2-9 років, еякуляти низької та високої якості ділили на спермальну плазму та сперматозоїди. Після поділу сперми на складові у спермальній плазмі та сперматозоїдах методом полуменевої фотометрії $[4 ; 7]$ визначали концентрацію $\mathrm{Ca}^{2+}, \mathrm{K}^{+}$та $\mathrm{Na}^{+}$. Ліміт концентрації сперматозоїдів в еякулятах дослідних груп (1-3) становив 0,062,25 млрд./см ${ }^{3}$ сперми. Для зручності аналізу еякуляти трьох груп бугаїв виокремили у 7 підгруп. Визначений середній показник рівня концентрації сперматозоїдів в еякулятах першої підгрупи складав $0,16-0,17$, другої - 0,46-0,47, третьої - 0,75-0,78, четвертої - 1,05-1,08, п'ятої - 1,35-1,38, шостої - 1,74-1,77, сьомої - 2,072,18 млрд./см ${ }^{3}$ сперми.

Оскільки середні показники концентрації сперматозоїдів в еякулятах першої та другої підгруп - низькі $(0,16-0,47$ млрд./см³), вважаємо, що генеративна діяльність тканин яєчок і придаткових статевих залоз на момент досліджень перебуває у стані гіпофункції. Діяльність, яка забезпечує середню $\left(0,75-1,38\right.$ млрд./см $\left.{ }^{3}\right)$ концентрацію сперматозоїдів в еякулятах третьої, четвертої та п’ятої підгруп прийняли за нормо-, а діяльність, яка забезпечує іх високу (1,74-2,18 млрд./см³) концентрацію в еякулятах шостої та сьомої підгруп, - за гіперфункціональний стан (табл. 1-3).

Рівновагу вмісту, або гоместаз іонів солей лужних металів, оцінювали числовими виразами (ч. в.) співвідношень різно- $\left(\mathrm{Na}^{+}: \mathrm{K}^{+}, \mathrm{K}^{+}: \mathrm{Ca}^{2+}, \mathrm{Na}^{+}: \mathrm{Ca}^{2+}\right)$ та одноіменних $\left(\mathrm{Ca}^{2+}: \mathrm{Ca}^{2+}, \mathrm{K}^{+}: \mathrm{K}^{+}, \mathrm{Na}^{+}: \mathrm{Na}^{+}\right)$пар спермальної плазми, сперматозоїдів і сперми (спермальна плазма : сперматозоїди). Для цього високі значення концентрації $\mathrm{Ca}^{2+}, K^{+}$та $\mathrm{Na}^{+}$ділили на низькі (табл. 4, 5).

Результати досліджень аналізували методом варіаційної статистики [6] з використанням програми Microsoft Excel. Дані проведеного експерименту оцінювали показниками середнього арифметичного, стандартної похибки та вірогідності різниці.

\section{Результати та їх обговорення}

Аналіз показників концентрації $K^{+}$спермальної плазми, сперматозоїдів та ії суми у спермі дослідних груп бугаїв і підгруп еякулятів проводимо з позиції наведених вище мотивів гіпотези про можливість зв'язку інтенсивності перебігу генеративних, функціональних і біохімічних процесів у тканинах яєчок, які засновують наявність поліморфізму сперматозоїдів і придаткових залоз, що виділяють секрети спермальної плазми, з гомеостазом іонів солей лужних металів у спермі (табл. 1-3).

В еякулятах групи НКК із концентрацією сперматозоїдів 0,1-2,2 млрд./см ${ }^{3}$ сперми ліміт (min-max) концентрації $\mathrm{Ca}^{2+}$ спермальної плазми становить 5-9 мМ. Але якщо за нормофункції тканин статевих органів концентрація $\mathrm{Ca}^{2+}-$ середня $(7,5-8,2)$, за гіпо- - висока $(7,8-9,1)$, то за гіпер- - низька $(5,4-6,1$ мМ). У відокремлених від спермальної плазми сперматозоїдах ліміт концентрації $\mathrm{Ca}^{2+}$ за їх нормофункції становить 1,7-2,0 мМ. Дуже низька $(0,17)$ і дуже висока $\left(2,07\right.$ млрд./см $\left.{ }^{3}\right)$ концентрації 
сперматозоїдів в еякулятах, відповідно, знижують $(1,45)$ і підвищують $(2,13$ мМ) концентрацію $\mathrm{Ca}^{2+}$ у клітинах. Звідси можна зробити висновок, що вірогідні $(p<0,01-$ $0,001)$ зміни концентрації $\mathrm{Ca}^{2+}$ у спермі зумовлені інтенсивністю функцій придаткових залоз і яєчок. Іншими словами, наведений висновок означає, що за гіпо- та гіперфункції тканин генеративні, біохімічні та біофізичні процеси, які відбуваються у статевих органах бугаїв, ініціюють дестабілізацію гомеостазу $\mathrm{Ca}^{2+}$ у спермі (див. табл. 1).

За гіпо-, нормо- та гіперфункції генеративних тканин придаткових залоз ліміт концентрації $K^{+}$спермальної плазми у підгрупах 1-7 становить 13,48-22,73 мМ. При цьому низькі (12,77-14,22 мМ) концентрації $K^{+}$спермальної плазми властиві еякулятам бугаїв, генеративні процеси тканин статевих органів яких перебувають у стані нормо- $\left(0,77-1,38\right.$ млрд./см $\left.{ }^{3}\right)$, а високі $(15,71-16,25$ і $16,39-22,73 \mathrm{MM})$ - у стані гіпо-

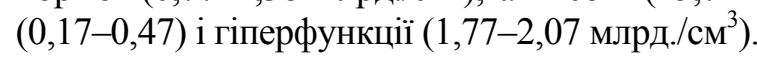

Таблиия 1

Концентрації сперматозоїдів та іонів в еякулятах групи НКК (мМ)

\begin{tabular}{|c|c|c|c|c|c|c|c|c|c|c|c|c|}
\hline \multirow[b]{2}{*}{ 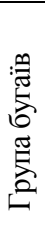 } & \multirow[b]{2}{*}{ 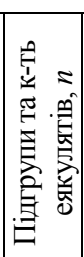 } & \multirow[b]{2}{*}{ 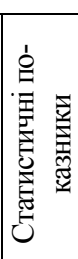 } & \multirow[b]{2}{*}{ 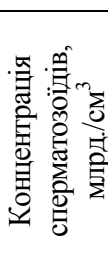 } & \multicolumn{3}{|c|}{$\mathrm{Ca}^{2+}$} & \multicolumn{3}{|c|}{$K^{+}$} & \multicolumn{3}{|c|}{$\mathrm{Na}^{+}$} \\
\hline & & & & 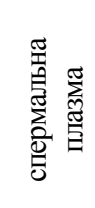 & 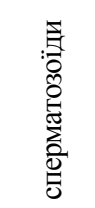 & W & 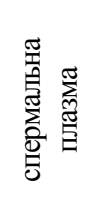 & 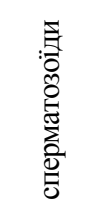 & W & 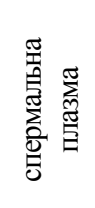 & 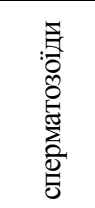 & $\omega$ \\
\hline \multirow{20}{*}{1} & \multirow{2}{*}{$\begin{array}{c}1 . \\
10\end{array}$} & $\mathrm{M}$ & 0,17 & 7,79 & 1,45 & 9,25 & 15,71 & 2,92 & 18,63 & 100,72 & 15,36 & 116,09 \\
\hline & & $\pm \mathrm{m}$ & 0,06 & 0,45 & 0,39 & 0,78 & 1,64 & 0,33 & 1,38 & 1,94 & 4,05 & 4,34 \\
\hline & \multicolumn{2}{|c|}{$\mathrm{P} 11^{1}: 1^{4^{*}}$} & $<0,001$ & $>0,5$ & $>0,2$ & $>0,5$ & $>0,2$ & $<0,001$ & $>0,5$ & $<0,001$ & $>0,2$ & $<0,01$ \\
\hline & \multirow{2}{*}{$\begin{array}{l}2 . \\
27\end{array}$} & $\mathrm{M}$ & 0,47 & 9,10 & 1,92 & 11,02 & 16,25 & 4,67 & 21,39 & 87,78 & 20,21 & 108,06 \\
\hline & & \begin{tabular}{|l|}
$\pm \mathrm{m}$ \\
\end{tabular} & 0,06 & 0,30 & 0,02 & 0,31 & 0,97 & 0,60 & 1,60 & 3,86 & 0,23 & 3,84 \\
\hline & \multicolumn{2}{|c|}{$\mathrm{P} 1^{2}: 1^{4^{*}}$} & $<0,001$ & $<0,01$ & $>0,2$ & $<0,02$ & $<0,05$ & $>0,2$ & $>0,2$ & $>0,1$ & $>0,2$ & $>0,1$ \\
\hline & \multirow{2}{*}{$\begin{array}{l}3 . \\
45\end{array}$} & $\mathrm{M}$ & 0,77 & 8,19 & 1,98 & 10,18 & 12,77 & 5,40 & 18,18 & 77,78 & 22,05 & 99,83 \\
\hline & & \begin{tabular}{|l|}
$\pm \mathrm{m}$ \\
\end{tabular} & 0,04 & 0,23 & 0,09 & 0,27 & 0,67 & 0,17 & 0,84 & 3,66 & 0,59 & 4,11 \\
\hline & \multicolumn{2}{|c|}{$\mathrm{P} 1^{3}: 1^{4^{*}}$} & \begin{tabular}{|l|}
$<0,001$ \\
\end{tabular} & $>0,2$ & $>0,2$ & $>0,1$ & $>0,1$ & $>0,5$ & $>0,5$ & $>0,5$ & $>0,2$ & $>0,5$ \\
\hline & \multirow{2}{*}{$\begin{array}{l}4 . \\
39\end{array}$} & $\mathrm{M}$ & 1,06 & 7,72 & 1,81 & 9,53 & 13,48 & 5,35 & 18,81 & 78,58 & 20,96 & 99,55 \\
\hline & & $\pm \mathrm{m}$ & 0,07 & 0,32 & 0,10 & 0,42 & 0,70 & 0,25 & 0,95 & 3,81 & 0,57 & 3,27 \\
\hline & \multicolumn{2}{|c|}{$\mathrm{P} 1^{5}: 1^{4^{*}}$} & $<0,01$ & $>0,5$ & $>0,2$ & $>0,5$ & $>0,5$ & $>0,2$ & $>0,5$ & $\frac{, 01}{>0,5}$ & $>0,5$ & $>0,5$ \\
\hline & \multirow{2}{*}{$\begin{array}{c}5 . \\
10\end{array}$} & $\mathrm{M}$ & 1,38 & 7,54 & 1,69 & 9,23 & 14,22 & 5,64 & 19,86 & 79,02 & 21,34 & 100,36 \\
\hline & & \begin{tabular}{|l|}
$\pm \mathrm{m}$ \\
\end{tabular} & 0,06 & 0,09 & 0,10 & 0,10 & 1,04 & 0,32 & 1,35 & 1,97 & 1,43 & 3,38 \\
\hline & \multicolumn{2}{|c|}{$\mathrm{P} 1^{6}: 1^{4^{*}}$} & $<0,001$ & $<0,05$ & $>0,5$ & $<0,05$ & $<0,02$ & $<0,001$ & $<0,001$ & $>0,1$ & $<0,01$ & $>0,2$ \\
\hline & \multirow{2}{*}{$\begin{array}{c}6 . \\
11\end{array}$} & $\mathrm{M}$ & 1,77 & 6,07 & 1,88 & 7,94 & 16,39 & 7,12 & 23,71 & 71,14 & 24,27 & 95,41 \\
\hline & & $\pm \mathrm{m}$ & 0,05 & 0,65 & 0,02 & 0,63 & 0,72 & 0,32 & 0,68 & 1,84 & 0,93 & 1,12 \\
\hline & \multicolumn{2}{|c|}{$\mathrm{P} 1^{7}: 1^{4^{*}}$} & $<0,001$ & $<0,001$ & $<0,01$ & $<0,001$ & $<0,001$ & $<0,001$ & $<0,001$ & $>0,1$ & $<0,001$ & $>0,5$ \\
\hline & \multirow{2}{*}{$\begin{array}{l}7 . \\
9\end{array}$} & $M$ & 2,07 & 5,40 & 2,13 & 7,53 & 22,73 & 10,52 & 32,72 & 71,74 & 25,65 & 97,39 \\
\hline & & $\pm \mathrm{m}$ & 0,06 & 0,22 & 0,04 & 0,23 & 0,47 & 0,17 & 0,66 & 2,69 & 0,47 & 3,15 \\
\hline
\end{tabular}

Примітка: Р $1^{1-3}: 1^{4^{*}} \ldots 1^{5-7}: 1^{4^{*}}$ - вірогідність різниці концентрації $\mathrm{Ca}^{2+}, \mathrm{K}^{+}$та $\mathrm{Na}^{+}$між групами еякулятів $\left(1^{4}\right)_{3}$ оптимальною $\left(1,06^{4}\right)$ концентрацією сперматозоїдів та ії мінімальними $\left(0,17^{1}, 0,47^{2}, 0,77^{3}\right)$ і максимальними $\left(1,38^{5}\right.$, $1,77^{6}, 2,07^{7}$ млрд./см $\left.{ }^{3}\right)$ показниками.

У сперматозоїдах за нормофункції генеративних тканин статевих органів визначили середню $(5,4-5,6)$, за гіпер- - високу $(7,1-10,5)$, а за гіпо- - низьку $(2,9-4,7$ мМ) концентрацію $K^{+}$. Вказані зміни концентрації властиві також показникам іiі суми. Проаналізовані результати досліджень вказують на те, що дестабілізація гомеостазу $K^{+}$ пов'язана $з$ функціональним станом тканин статевих органів. При цьому гіпофункціональний стан вірогідно підвищує концентрацію $K^{+}$у спермальній плазмі $(p<0,05)$ i 
знижує у сперматозоїдах ( $p<0,001)$, а гіпер- - зумовлює іï вірогідно $(p<0,001)$ вищий рівень у спермальній плазмі та сперматозоїдах.

Ліміт середніх значень концентрації $\mathrm{Na}^{+}$спермальної плазми еякулятів групи НКК становить 71,74-100,72 мМ. За нормофункцій тканин рівень $\mathrm{Na}^{+}$стабільно середній $(77,78-79,02)$, за гіпо- - високий $(87,78-100,72)$, за гіпер- - низький $(71,14$ $71,74 \mathrm{мM})$. Але у відокремленій від спермальної плазми масі сперматозоїдів першої та другої підгруп еякулятів вектор накопичення вмісту $\mathrm{Na}^{+}(\min -15,36, \max -24,27 \mathrm{мM})$ спрямований від низької $(0,17-0,47)$ до високої $\left(1,77-2,07\right.$ млрд./см $\left.{ }^{3}\right)$ концентрації сперматозоїдів. Сума концентрацій $\mathrm{Na}^{+}$спермальної плазми та сперматозоїдів за нормофункції тканин виражена іï середніми $(99,55-100,36)$, за гіпо- - високими $(108,06-116,09)$, а за гіпер- - низькими (95,41-97,39 мМ) показниками. Вірогідне $(p<0,001)$ підвищення концентрації $\mathrm{Na}^{+}$характерне для спермальної плазми першої (гіперфункції придаткових залоз) та сперматозоїдів шостої та сьомої підгруп еякулятів (гіперфункції яєчок).

Табличя 2

Концентрації сперматозоїдів та іонів в еякулятах групи СКК (мМ)

\begin{tabular}{|c|c|c|c|c|c|c|c|c|c|c|c|c|}
\hline \multirow[b]{2}{*}{ 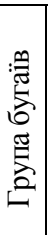 } & \multirow[b]{2}{*}{ 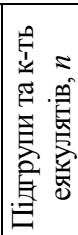 } & \multirow[b]{2}{*}{ 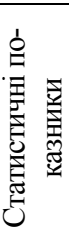 } & \multirow[b]{2}{*}{ 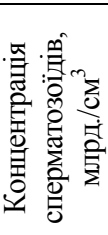 } & \multicolumn{3}{|c|}{$\mathrm{Ca}^{2+}$} & \multicolumn{3}{|c|}{$K^{+}$} & \multicolumn{3}{|c|}{$\mathrm{Na}^{+}$} \\
\hline & & & & 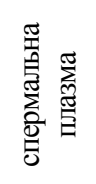 & 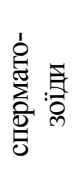 & W & 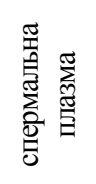 & 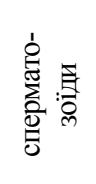 & W & 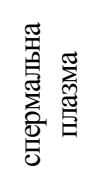 & 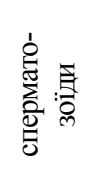 & W \\
\hline \multirow{20}{*}{2} & \multirow{2}{*}{$\begin{array}{c}1 . \\
22\end{array}$} & $\mathrm{M}$ & 0,16 & 5,48 & 1,36 & 6,83 & 27,59 & 7,20 & 34,79 & 78,31 & 14,91 & 93,22 \\
\hline & & $\pm \mathrm{m}$ & 0,06 & 1,74 & 0,36 & 2,09 & 3,11 & 2,04 & 5,12 & 2,11 & 1,29 & 1,99 \\
\hline & \multicolumn{2}{|c|}{ P $2^{1}: 2^{4^{*}}$} & $<0,001$ & $>0,2$ & $>0,2$ & $>0,5$ & $>0,2$ & $>0,2$ & $>0,5$ & $<0,001$ & $<0,01$ & $<0,001$ \\
\hline & \multirow{2}{*}{$\begin{array}{l}2 . \\
85\end{array}$} & $\mathrm{M}$ & 0,46 & 7,85 & 1,89 & 9,73 & 27,16 & 11,06 & 38,22 & 74,81 & 18,27 & 93,75 \\
\hline & & $\pm \mathrm{m}$ & 0,06 & 0,45 & 0,08 & 0,53 & 1,71 & 0,38 & 2,05 & 0,76 & 0,24 & 0,46 \\
\hline & \multicolumn{2}{|c|}{$\mathrm{P} 2^{2}: 2^{4^{*}}$} & $<0,001$ & $<0,001$ & $>0,5$ & $>0,5$ & $>0,2$ & $>0,05$ & $>0,2$ & $<0,001$ & $>0,5$ & $<0,001$ \\
\hline & \multirow{2}{*}{$\begin{array}{c}3 . \\
130\end{array}$} & $M$ & 0,78 & 6,76 & 1,76 & 8,63 & 25,69 & 10,82 & 36,51 & 73,90 & 20,40 & 94,30 \\
\hline & & $\pm \mathrm{m}$ & 0,06 & 0,13 & 0,12 & 0,30 & 0,90 & 0,59 & 0,50 & 1,24 & 0,43 & 1,65 \\
\hline & \multicolumn{2}{|c|}{$\mathrm{P} 2^{3}: 2^{4^{*}}$} & $<0,001$ & $>0,05$ & $>0,5$ & $>0,5$ & $>0,5$ & $>0,5$ & $>0,5$ & $>0,05$ & $<0,001$ & $<0,01$ \\
\hline & \multirow{2}{*}{$\begin{array}{c}4 . \\
93 \\
\end{array}$} & $\mathrm{M}$ & 1,05 & 6,09 & 1,68 & 7,78 & 25,17 & 9,94 & 35,11 & 70,31 & 17,95 & 88,26 \\
\hline & & $\pm \mathrm{m}$ & 0,05 & 0,33 & 0,06 & 0,34 & 1,42 & 0,44 & 1,83 & 1,02 & 0,54 & 1,55 \\
\hline & \multicolumn{2}{|c|}{$\mathrm{P} 2^{5}: 2^{4^{*}}$} & $<0,001$ & $>0,5$ & $>0,5$ & $>0,2$ & $>0,1$ & $<0,001$ & $<0,02$ & $>0,2$ & $>0,5$ & $>0,5$ \\
\hline & \multirow{2}{*}{$\begin{array}{l}5 . \\
48\end{array}$} & $M$ & 1,36 & 6,43 & 1,73 & 8,15 & 28,83 & 12,51 & 41,33 & 66,33 & 18,25 & 84,57 \\
\hline & & $\pm \mathrm{m}$ & 0,07 & 0,09 & 0,08 & 0,13 & 1,65 & 0,41 & 1,85 & 5,63 & 0,51 & 6,13 \\
\hline & \multicolumn{2}{|c|}{$\mathrm{P} 2^{6}: 2^{4^{*}}$} & $<0,001$ & $>0,2$ & $>0,5$ & $>0,2$ & $>0,2$ & $>0,1$ & $>0,5$ & $<0,001$ & $>0,2$ & $<0,05$ \\
\hline & \multirow{2}{*}{$\begin{array}{c}6 . \\
38 \\
\end{array}$} & $\mathrm{M}$ & 1,74 & 5,59 & 1,77 & 7,36 & 26,54 & 11,45 & 35,99 & 64,37 & 18,83 & 83,20 \\
\hline & & $\pm \mathrm{m}$ & 0,05 & 0,24 & 0,04 & 0,28 & 1,27 & 1,06 & 1,67 & 1,14 & 0,71 & 1,84 \\
\hline & \multicolumn{2}{|c|}{ P $2^{7}: 2^{4^{*}}$} & $<0,001$ & $<0,01$ & $>0,5$ & $<0,01$ & $<0,001$ & $<0,001$ & $<0,001$ & $<0,001$ & $>0,5$ & $<0,001$ \\
\hline & \multirow{2}{*}{$\begin{array}{c}7 . \\
35\end{array}$} & $\mathrm{M}$ & 2,12 & 5,03 & 1,78 & 6,81 & 30,99 & 14,39 & 45,38 & 53,64 & 17,80 & 71,44 \\
\hline & & $\pm \mathrm{m}$ & 0,09 & 0,14 & 0,06 & 0,10 & 0,47 & 0,45 & 0,86 & 3,43 & 0,33 & 3,64 \\
\hline
\end{tabular}

Примітка: Р $2^{1-3}: 2^{4^{*}} \ldots 2^{5-7}: 2^{4^{*}}$ - вірогідність різниці концентрації $\mathrm{Ca}^{2+}, K^{+}$та $\mathrm{Na}^{+}$між групами еякулятів $\left(2^{4}\right){ }_{3}$ оптимальною $\left(1,05^{4}\right)$ концентрацією сперматозоїдів та ії мінімальними $\left(0,16^{1}, 0,46^{2}, 0,78^{3}\right)$ і максимальними $\left(1,36^{5}\right.$,

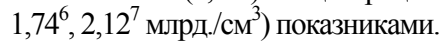

Аналіз результатів досліджень концентрації $\mathrm{Ca}^{2+}, \mathrm{K}^{+}$та $\mathrm{Na}^{+}$спермальної плазми та сперматозоїдів еякулятів групи НКК свідчить про те, що дестабілізацію гомеостазу $\mathrm{Ca}^{2+}$ у спермі слід пов'язувати з гіпо- та гіперфункціями придаткових залоз ( $p<0,01$, $0,02,0,001)$, але сперматозоїдів - із гіперфункціями яєчок; $K^{+}-$із гіпо- та гіперфункціями придаткових залоз і яєчок ( $p<0,05,0,001), \mathrm{a} \mathrm{Na}^{+}-$із гіпо- придаткових залоз і гіперяєчок $(p<0,001)$. 
Оскільки ліміт концентрації $K^{+}$в еякулятах бугаїв групи НКК становить 18,18 32,72, а у СКК - 34,79-45,38 мМ, що в 1,4-1,9 раза більше, то виявлена невідповідність вимагає детального аналізу змін концентрації $\mathrm{Ca}^{2+}, \mathrm{K}^{+}$та $\mathrm{Na}^{+}$спермальної плазми, сперматозоїдів та їх суми, залежно від концентрації статевих клітин $\left(0,16-2,12\right.$ млрд./см $\left.{ }^{3}\right)$ у спермі (див. табл. 2).

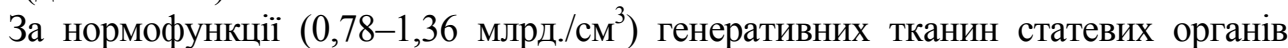
ліміт середніх значень концентрації $\mathrm{Ca}^{2+}$ у спермальній плазмі становить 6,096,76 мМ. Їх гіпер- і гіпофункції знижують концентрацію $\mathrm{Ca}^{2+}$ відповідно з 5,59 до 5,03 та з 7,85 до 5,48 мМ. Середня концентрація $\mathrm{Ca}^{2+}$ у сперматозоїдах за нормофункції тканин зберігається стабільно однаковою $(1,68-1,76 \mathrm{мM})$; за гіпер- - не виходить за визначені для нормофункції концентрації, а за гіпо- - знижується з 1,89 до 1,36 мМ. Вказаний розподіл концентрації $\mathrm{Ca}^{2+}$ характерний також сумі ії показників у спермі. Вірогідну $(p<0,01)$ зміну концентрації виявили лише у спермальній плазмі за гіперфункції тканин.

Нормофункції тканин характеризують стабільно однакові концентрації $K^{+}$спермальної плазми (25,17-28,83), сперматозоїдів (9,94-12,51), сперми (35,11-41,33 мМ). Вірогідні $(p<0,001)$ зміни концентрації $K^{+}$пов'язані з гіперфункцією придаткових залоз і яєчок, за яких іiі середні значення для спермальної плазми зростають із 26,54 до 30,99, а для сперматозоїдів - із 11,45 до 14,39 мМ.

Чутливою ланкою гомеостазу іонів слід уважати рівновагу вмісту $\mathrm{Na}^{+}$у спермі. Ïї вірогідну $(p<0,001)$ зміну за нормофункції тканин виявили у спермальній плазмі п’ятої $(1,36)$ та у сперматозоїдах третьої $\left(0,78\right.$ млрд./см $\left.{ }^{3}\right)$ підгруп. Якщо за гіперфункції у спермальній плазмі та сперматозоїдах концентрація $\mathrm{Na}^{+}$зменшується відповідно із 64,37 до 53,64 та із 18,27 до 14,91, то за гіпофункції у спермальній плазмі - зростає із 74,81 до 78,31 мМ.

Аналіз концентрації $\mathrm{Ca}^{2+}, \mathrm{K}^{+}$та $\mathrm{Na}^{+}$спермальної плазми та сперматозоїдів в еякулятах групи СКК свідчить про те, що вірогідна $(p<0,01)$ зміна концентрації $\mathrm{Ca}^{2+}$ властива спермальній плазмі за гіперфункції тканин, $K^{+}-$пов'язана із гіперфункціями придаткових залоз і яєчок, за яких ії середні значення у спермальній плазмі зростають із 26,54 до 30,99 , у сперматозоїдах - із 11,45 до $14,39 \mathrm{MM}, \mathrm{Na}^{+}$- дуже чутлива до змін інтенсивності генеративних функцій тканин придаткових залоз і яєчок.

Оскільки в еякулятах групи ВКК ліміт середніх значень концентрації $K^{+}$у спермі становить 44,92-65,56 мМ, що в 1,3-1,4 раза більше, ніж у СКК та в 2,0-2,5 раза більше, ніж у НКК, то екстраполяція проаналізованих особливостей розподілу концентрації $\mathrm{Ca}^{2+}, \mathrm{K}^{+}$та $\mathrm{Na}^{+}$у їх спермальній плазмі та сперматозоїдах на групу ВКК дає можливість стверджувати, що причини дестабілізації гомеостазу іонів в еякулятах цієї групи також пов'язані з інтенсивністю перебігу генеративних процесів у тканинах органів статевої системи (див. табл. 3).

За нормофункції генеративних тканин $\left(0,75-1,35\right.$ млрд./см $\left.{ }^{3}\right)$ ліміт середніх значень концентрації $\mathrm{Ca}^{2+}$ у спермальній плазмі еякулятів групи ВКК становить 7,218,09 мМ. За гіперфункції - не виходить за визначені параметри норми, а за гіпо- вірогідно $(p<0,001)$ знижується із 7,88 до 4,26 мМ. Зміну норми концентрації $\mathrm{Ca}^{2+}$ у

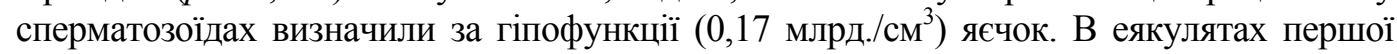
підгрупи іiі середній показник вірогідно $(p<0,001)$ менший $(0,61)$, ніж четвертої (1,96 мМ). За гіперфункції концентрація $C a^{2+}$ у сперматозоїдах висока (2,22-2,31 мМ), але не виходить за межу норми. При цьому середні показники норми концентрації $\mathrm{Ca}^{2+}$ у сперматозоїдах еякулятів групи ВКК $(1,82-2,10)$ вищі, ніж груп СКК $(1,68-1,76)$ i НКК (1,69-1,98 мМ).

48 
Концентрації сперматозоїдів та іонів в еякулятах групи ВКК (мМ)

\begin{tabular}{|c|c|c|c|c|c|c|c|c|c|c|c|c|}
\hline \multirow[b]{2}{*}{ 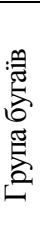 } & \multirow[b]{2}{*}{ 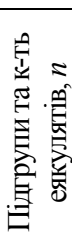 } & \multirow[b]{2}{*}{ 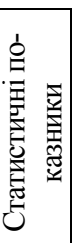 } & \multirow[b]{2}{*}{ 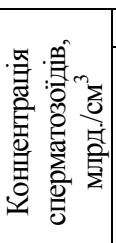 } & \multicolumn{3}{|c|}{$\mathrm{Ca}^{2+}$} & \multicolumn{3}{|c|}{$K^{+}$} & \multicolumn{3}{|c|}{$\mathrm{Na}^{+}$} \\
\hline & & & & 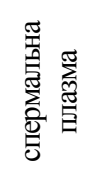 & 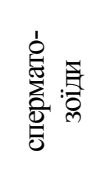 & $\omega$ & 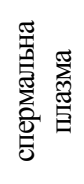 & 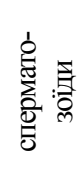 & $\omega$ & 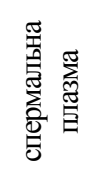 & 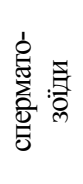 & $\omega$ \\
\hline \multirow{20}{*}{3} & 1. & $\mathrm{M}$ & 0,17 & 4,26 & 0,61 & 4,87 & 35,78 & 9,14 & 44,92 & 67,27 & 14,93 & 82,20 \\
\hline & 11 & $\pm \mathrm{m}$ & 0,06 & 0,64 & 0,03 & 0,67 & 5,39 & 1,90 & 7,19 & 1,36 & 1,59 & 2,31 \\
\hline & \multicolumn{2}{|c|}{$\mathrm{P} 3^{1}: 3^{4^{*}}$} & $<0,001$ & $<0,001$ & $<0,001$ & $<0,001$ & $<0,05$ & $<0,01$ & $<0,05$ & $<0,001$ & $>0,2$ & $<0,001$ \\
\hline & 2. & $\mathrm{M}$ & 0,46 & 7,88 & 1,76 & 9,64 & 50,44 & 15,11 & 65,56 & 61,68 & 13,43 & 75,11 \\
\hline & 15 & $\pm \mathrm{m}$ & 0,06 & 0,93 & 0,54 & 1,47 & 0,78 & 0,56 & 1,24 & 2,24 & 0,85 & 2,37 \\
\hline & \multicolumn{2}{|c|}{$\mathrm{P}^{2}: 3^{4^{*}}$} & $0,001<$ & $>0,5$ & $>0,5$ & $>0,5$ & $>0,5$ & $>0,5$ & $>0,5$ & $<0,001$ & $>0,5$ & $<0,001$ \\
\hline & 3. & $\mathrm{M}$ & 0,75 & 7,65 & 2,10 & 9,75 & 47,47 & 15,64 & 63,78 & 53,21 & 15,12 & 68,33 \\
\hline & 14 & $\pm \mathrm{m}$ & 0,05 & 0,23 & 0,08 & 0,17 & 2,27 & 1,86 & 1,68 & 4,08 & 1,94 & 5,70 \\
\hline & \multicolumn{2}{|c|}{$\mathrm{P} 3^{3}: 3^{4^{*}}$} & $<0,001$ & $>0,5$ & $>0,5$ & $>0,5$ & $>0,2$ & $>0,5$ & $>0,5$ & $>0,5$ & $>0,5$ & $<0,001$ \\
\hline & 4. & $\mathrm{M}$ & 1,08 & 8,09 & 1,96 & 10,05 & 50,49 & 14,95 & 65,44 & 50,65 & 13,23 & 63,89 \\
\hline & 13 & $\pm \mathrm{m}$ & 0,06 & 0,42 & 0,16 & 0,40 & 1,95 & 0,32 & 2,25 & 0,19 & 1,11 & 1,10 \\
\hline & \multicolumn{2}{|c|}{$\mathrm{P} 3^{5}: 3^{4^{*}}$} & $<0,01$ & $>0,05$ & $>0,2$ & $>0,02$ & $>0,1$ & $<0,01$ & $<0,001$ & $>0,5$ & $>0,1$ & $<0,001$ \\
\hline & \multirow{2}{*}{$\begin{array}{l}5 . \\
15 \\
\end{array}$} & $\mathrm{M}$ & 1,35 & 7,21 & 1,82 & 9,03 & 47,47 & 16,68 & 64,16 & 49,90 & 16,22 & 66,12 \\
\hline & & $\pm \mathrm{m}$ & 0,06 & 0,22 & 0,02 & 0,20 & 1,17 & 0,25 & 1,40 & 1,01 & 1,28 & 2,22 \\
\hline & \multicolumn{2}{|c|}{$\mathrm{P} 3^{6}: 3^{4^{*}}$} & $<0,001$ & $>0,5$ & $>0,1$ & $>0,5$ & $<0,01$ & $>0,5$ & $<0,02$ & $<0,001$ & $>0,5$ & $<0,001$ \\
\hline & \multirow{2}{*}{$\begin{array}{c}6 . \\
10 \\
\end{array}$} & $\mathrm{M}$ & 1,74 & 7,98 & 2,22 & 10,20 & 43,55 & 15,21 & 58,76 & 47,39 & 13,76 & 61,15 \\
\hline & & $\pm \mathrm{m}$ & 0,07 & 0,09 & 0,07 & 0,14 & 0,54 & 0,24 & 0,66 & 0,63 & 0,27 & 0,61 \\
\hline & \multicolumn{2}{|c|}{$\mathrm{P} 3^{7}: 3^{4^{*}}$} & $<0,001$ & $>0,2$ & $>0,1$ & $>0,5$ & $<0,02$ & $<0,05$ & $<0,05$ & $<0,05$ & $>0,5$ & $<0,001$ \\
\hline & \multirow{2}{*}{$\begin{array}{l}7 . \\
10 \\
\end{array}$} & $\mathrm{M}$ & 2,18 & 7,74 & 2,31 & 10,05 & 45,42 & 14,05 & 59,47 & 46,79 & 13,25 & 60,05 \\
\hline & & $\pm \mathrm{m}$ & 0,09 & 0,27 & 0,18 & 0,11 & 0,57 & 0,26 & 0,79 & 0,43 & 0,19 & 0,29 \\
\hline
\end{tabular}

Примітка: Р $3^{1-3}: 3^{4^{*}} \ldots 3^{5-7}: 3^{4^{*}}$ - вірогідність різниці концентрації $\mathrm{Ca}^{2+}, \mathrm{K}^{+}$та $\mathrm{Na}^{+}$між групами еякулятів $\left(3^{4}\right){ }_{3}$ оптимальною $\left(1,08^{4}\right)$ концентрацією сперматозоїдів та ії мінімальними $\left(0,17^{1}, 0,46^{2}, 0,75^{3}\right)$ і максимальними $\left(1,35^{5}\right.$, $1,74^{6}, 2,18^{7}$ млрд./см $\left.{ }^{3}\right)$ показниками.

У спермальній плазмі ліміт концентрації $K^{+}$за нормофункції становить 47,4750,49 мМ. Однак про можливість впливу гіпо- та гіперфункціональних станів статевих органів на параметри іï норми вказує лише визначена тенденція $(p<0,05,0,01,0,02)$ до зниження рівнів спермальної плазми першої, шостої та сьомої та сперматозоїдів першої та сьомої підгруп еякулятів.

Висока вірогідність $(p<0,001)$ зниження концентрації $\mathrm{Na}^{+}$властива спермальній плазмі. Ліміт їі мінімальних і максимальних значень за нормофункції становить 49,9053,21 мМ. Якщо показники ліміту концентрації $\mathrm{Na}^{+}$за гіпофункції $(61,68-67,27)-$ високі, за гіпер- $(46,79-47,39)$ - низькі, то у сперматозоїдах за усіх функціональних станів (13,23-16,22 мМ) - стабільно однакові.

Проаналізовані концентрації $\mathrm{Ca}^{2+}, \mathrm{K}^{+}$та $\mathrm{Na}^{+}$в еякулятах групи ВКК свідчать про те, що за гіперфункції тканин статевої системи бугаїв концентрація $\mathrm{Ca}^{2+}$ у спермальній плазмі та сперматозоїдах не виходить за ліміт норми, а за гіпо- - зменшується; $K^{+}$за гіпер- та гіпо- - виражена тенденцією до змін у спермальній плазмі та сперматозоїдах; $\mathrm{Na}^{+}$за гіпо- - висока у спермальній плазмі, за гіпер- - низька, а у сперматозоїдах за гіпо-, нормо- та гіперфункції - стабільно однакова.

Повніше та об’єктивніше відображення земін гомеостазу іонів, що відбуваються в еякулятах бугаїв дослідних груп за нормо-, гіпо- та гіперфункціональних станів органів статевої системи, можна отримати 3 оцінки співвідношень різно- та 
одноіменних пар $\mathrm{Ca}^{2+}, \mathrm{K}^{+}$та $\mathrm{Na}^{+}$у спермальній плазмі, сперматозоїдах та між ними. 3 огляду на це, у таблицях 4 та 5 наводимо динаміку виразів, яка характеризує особливості рівноваги вмісту іонів в еякулятах високої та низької якості.

Результати аналізу числових виразів свідчать про те, що за нормофункції тканин репродуктивних органів найвищий (4-6:1) показник співвідношень $\mathrm{Na}^{+}: K^{+}$властивий еякулятам групи НКК (див. табл. 4). При цьому їх високі значення у спермальній плазмі (6:1) і низькі у сперматозоїдах (4:1) зумовлюють середні у спермі (5:1). В еякулятах групи СКК (2-3:1) співвідношення $\mathrm{Na}^{+}: \mathrm{K}^{+}$в $2,0-2,5$, а у ВКК $(1: 1)$ в 4-6 разів менше, ніж у НКК (4-6:1). За гіпофункції тканин ліміт відхилень від визначеної для еякулятів групи НКК норми співвідношень $\mathrm{Na}^{+}: \mathrm{K}^{+}$- дуже широкий (4-16:1). Виявлено також неоднакову реакцію рівноваги вмісту іонів на зміну фунціональних станів тканин статевих органів. Якщо вектор змін відношення концентрації $\mathrm{Na}^{+}$щодо $\mathrm{K}^{+}$за гіпофункції спрямований у бік збільшення значень числового виразу (16:1), то за гіпер- у бік зменшення $(2: 1)$.

Таблиия 4

Співвідношення $\mathrm{Ca}^{2+}, \mathrm{K}^{+}$та $\mathrm{Na}^{+}$у спермальній плазмі, сперматозоїдах, спермі (ч. в.)

\begin{tabular}{|c|c|c|c|c|c|c|c|c|c|c|}
\hline \multirow{3}{*}{$\begin{array}{l}\text { Групи } \\
\text { бугаїв }\end{array}$} & \multirow{3}{*}{$\begin{array}{l}\text { Під- } \\
\text { групи } \\
\text { еяку- } \\
\text { лятів }\end{array}$} & \multicolumn{9}{|c|}{ Різноіменні пари } \\
\hline & & \multicolumn{3}{|c|}{$\mathrm{Na}^{+}: \mathrm{K}^{+}$} & \multicolumn{3}{|c|}{$K^{+}: \mathrm{Ca}^{2+}$} & \multicolumn{3}{|c|}{$\mathrm{Na}^{+}: \mathrm{Ca}^{2+}$} \\
\hline & & $\begin{array}{c}\text { сп. } \\
\text { пл.* }\end{array}$ & кл.* & c., $\Sigma^{*}$ & $\begin{array}{c}\text { сп. } \\
\text { пл.* }\end{array}$ & кл.* & c., $\Sigma^{*}$ & $\begin{array}{c}\text { сп. } \\
\text { пл.* }\end{array}$ & кл.* & c., $\Sigma^{*}$ \\
\hline \multirow{7}{*}{1} & 1 & $16: 1$ & $5: 1$ & $6: 1$ & $2: 1$ & $2: 1$ & $2: 1$ & 13:1 & $11: 1$ & 13:1 \\
\hline & 2 & $5: 1$ & $4: 1$ & $5: 1$ & $2: 1$ & $2: 1$ & $2: 1$ & $10: 1$ & $11: 1$ & $10: 1$ \\
\hline & 3 & $6: 1$ & $4: 1$ & $5: 1$ & $2: 1$ & $3: 1$ & $2: 1$ & $9: 1$ & $11: 1$ & $10: 1$ \\
\hline & 4 & $6: 1$ & $4: 1$ & $5: 1$ & $2: 1$ & $3: 1$ & $2: 1$ & $10: 1$ & $12: 1$ & $10: 1$ \\
\hline & 5 & $6: 1$ & $4: 1$ & $5: 1$ & $2: 1$ & $3: 1$ & $2: 1$ & $10: 1$ & $13: 1$ & 11:1 \\
\hline & 6 & $5: 1$ & $3: 1$ & $4: 1$ & $3: 1$ & $3: 1$ & $3: 1$ & $9: 1$ & $13: 1$ & $10: 1$ \\
\hline & 7 & $3: 1$ & $2: 1$ & $3: 1$ & $4: 1$ & $4: 1$ & $4: 1$ & 10:1 & $11: 1$ & $13: 1$ \\
\hline \multirow{7}{*}{2} & 1 & $3: 1$ & $2: 1$ & $2: 1$ & $5: 1$ & $5: 1$ & $5: 1$ & $14: 1$ & $10: 1$ & $11: 1$ \\
\hline & 2 & $3: 1$ & $2: 1$ & $2: 1$ & $3: 1$ & $6: 1$ & $4: 1$ & 10:1 & $10: 1$ & $8: 1$ \\
\hline & 3 & $3: 1$ & $2: 1$ & $2: 1$ & $4: 1$ & $6: 1$ & $4: 1$ & 11:1 & $12: 1$ & $9: 1$ \\
\hline & 4 & $3: 1$ & $2: 1$ & $2: 1$ & $4: 1$ & $6: 1$ & $5: 1$ & $12: 1$ & $11: 1$ & $9: 1$ \\
\hline & 5 & $2: 1$ & $2: 1$ & 2:1 & $4: 1$ & $7: 1$ & $5: 1$ & $10: 1$ & $11: 1$ & $8: 1$ \\
\hline & 6 & $2: 1$ & $2: 1$ & $2: 1$ & $5: 1$ & $6: 1$ & $5: 1$ & 12:1 & $11: 1$ & $9: 1$ \\
\hline & 7 & $2: 1$ & $1: 1$ & 1:1 & $6: 1$ & $8: 1$ & $7: 1$ & 11:1 & $10: 1$ & $8: 1$ \\
\hline \multirow{7}{*}{3} & 1 & $2: 1$ & $2: 1$ & $2: 1$ & $8: 1$ & 15:1 & $10: 1$ & $16: 1$ & $24: 1$ & $17: 1$ \\
\hline & 2 & $1: 1$ & $1: 1$ & $1: 1$ & $6: 1$ & $8: 1$ & $7: 1$ & $8: 1$ & $8: 1$ & $8: 1$ \\
\hline & 3 & $1: 1$ & $1: 1$ & 1:1 & $6: 1$ & $7: 1$ & $7: 1$ & $7: 1$ & $7: 1$ & $7: 1$ \\
\hline & 4 & $1: 1$ & $1: 1$ & 1:1 & $6: 1$ & $8: 1$ & $7: 1$ & $6: 1$ & $7: 1$ & $6: 1$ \\
\hline & 5 & $1: 1$ & $1: 1$ & $1: 1$ & $7: 1$ & $9: 1$ & $7: 1$ & $7: 1$ & $9: 1$ & $7: 1$ \\
\hline & 6 & $1: 1$ & $1: 1$ & 1:1 & $5: 1$ & $7: 1$ & $6: 1$ & $6: 1$ & $6: 1$ & $6: 1$ \\
\hline & 7 & $1: 1$ & $1: 1$ & 1:1 & $6: 1$ & $6: 1$ & $6: 1$ & $6: 1$ & $6: 1$ & $6: 1$ \\
\hline
\end{tabular}

Примітка: сп. пл.* - співвідношення пар іонів у спермальній плазмі, кл.* - сперматозоїдах, с., $\Sigma^{*}$ - спермі (iз суми концентрацій у спермальній плазмі та сперматозоїдах).

Визначені в еякулятах групи СКК числові вирази співвідношень $\mathrm{Na}^{+}: \mathrm{K}^{+}-$стабільно однакові. Ліміт відхилень їх мінімальних і максимальних значень у спермальній плазмі становить 2-3:1; у сперматозоїдах - 2:1, і лише за гіперфункції тканин у спермальній плазмі та сперматозоїдах визначили на одну частину вмісту $\mathrm{Na}^{+}$менше, ніж $K^{+}$.

В еякулятах групи ВКК співвідношення $\mathrm{Na}^{+}: K^{+}$також константні. Ліміт відхилень їх числового виразу найменший (1-2:1), а кількість співвідносних частин вмісту іонів однакова (1:1). За гіпофункції тканин виявили незначну (+ одна частина вмісту) зміну 50 
значень числового виразу співвідношень $\mathrm{Na}^{+}: \mathrm{K}^{+}$у спермальній плазмі та сперматозоїдах. Однак їх середні значення за гіперфункції залишаються в межах норми $(1: 1)$.

Якщо числові вирази співвідношень $\mathrm{Na}^{+}: \mathrm{K}^{+}$в еякулятах групи НКК за нормофункції тканин високі (4-6:1), то $\mathrm{K}^{+}: \mathrm{Ca}^{2+}-$ низькі (2-3:1). У спермальній плазмі вони у 3 , а у сперматозоїдах - в 1,3 раза менші. Залежно від інтенсивності генеративних функцій їх дисбаланс не виходить за межу \pm 1 частина вмісту $K^{+}$щодо $C a^{2+}$. Зміна співвідношень $\mathrm{Na}^{+}: \mathrm{K}^{+}$та $\mathrm{K}^{+}: \mathrm{Ca}^{2+}$ у групі СКК за нормофункції тканин виражена протилежними величинами: числові вирази $\mathrm{Na}^{+}: \mathrm{K}^{+}$у спермальній плазмі в 1,3 раза менші, а у спермотозоїдах - в 3 рази більші, ніж $\mathrm{K}^{+}: \mathrm{Ca}^{2+}$. Невідповідність співвідношень пар іонів в еякулятах групи ВКК ще більша. Числові вирази $\mathrm{Na}^{+}: \mathrm{K}^{+}$у спермальній плазмі в 6-7; у сперматозоїдах у 7-9 разів більші, ніж $K^{+}: \mathrm{Ca}^{2+}$, а мінімальні та максимальні відхилення від норми, залежно від інтенсивності функції генеративних тканин, відповідно становлять $\pm 1-2$ частини вмісту $K^{+}$.

Таблицяя 5

Співвідношення $\mathrm{Ca}^{2+}, \mathrm{K}^{+}$та $\mathrm{Na}^{+}$між спермальною плазмою та сперматозоїдами (ч. в.)

\begin{tabular}{|c|c|c|c|c|c|c|c|c|}
\hline \multirow{3}{*}{ Об’єкт } & \multirow{3}{*}{$\begin{array}{l}\text { Групи } \\
\text { бугаїв }\end{array}$} & \multirow{3}{*}{$\begin{array}{l}\text { Підгрупи } \\
\text { еякулятів }\end{array}$} & \multicolumn{6}{|c|}{ Пари } \\
\hline & & & \multicolumn{3}{|c|}{ різноіменні } & \multicolumn{3}{|c|}{ одноіменні } \\
\hline & & & $\mathrm{Na}^{+}: \mathrm{K}^{+}$ & $\mathrm{K}^{+}: \mathrm{Ca}^{2+}$ & $\mathrm{Na}^{+}: \mathrm{Ca}^{2+}$ & $\mathrm{Ca}^{2+}: \mathrm{Ca}^{2+}$ & $K^{+}: K^{+}$ & $\mathrm{Na}^{+}: \mathrm{Na}^{+}$ \\
\hline \multirow{21}{*}{$\begin{array}{c}\text { Спермальна } \\
\text { плазма: } \\
\text { сперматозоїди }\end{array}$} & \multirow{7}{*}{1} & 1 & $34: 1$ & 11:1 & $69: 1$ & $5: 1$ & $5: 1$ & $7: 1$ \\
\hline & & 2 & 19:1 & $8: 1$ & $46: 1$ & $5: 1$ & $3: 1$ & $4: 1$ \\
\hline & & 3 & 14:1 & $6: 1$ & 39:1 & $4: 1$ & $2: 1$ & $4: 1$ \\
\hline & & 4 & 15:1 & $7: 1$ & $43: 1$ & $4: 1$ & $3: 1$ & $4: 1$ \\
\hline & & 5 & 14:1 & $8: 1$ & $47: 1$ & $4: 1$ & $3: 1$ & $4: 1$ \\
\hline & & 6 & $10: 1$ & $9: 1$ & $38: 1$ & $3: 1$ & $2: 1$ & $3: 1$ \\
\hline & & 7 & 10:1 & 11:1 & $34: 1$ & $3: 1$ & $2: 1$ & $3: 1$ \\
\hline & \multirow{7}{*}{2} & 1 & 11:1 & 19:1 & $54: 1$ & $4: 1$ & $4: 1$ & $5: 1$ \\
\hline & & 2 & $7: 1$ & 14:1 & $40: 1$ & $4: 1$ & $2: 1$ & $4: 1$ \\
\hline & & 3 & $7: 1$ & 14:1 & $42: 1$ & $4: 1$ & $2: 1$ & $4: 1$ \\
\hline & & 4 & $7: 1$ & 15:1 & $42: 1$ & $4: 1$ & $3: 1$ & $4: 1$ \\
\hline & & 5 & $5: 1$ & $17: 1$ & $38: 1$ & $4: 1$ & $2: 1$ & $4: 1$ \\
\hline & & 6 & $5: 1$ & $15: 1$ & $36: 1$ & $3: 1$ & $2: 1$ & $3: 1$ \\
\hline & & 7 & $4: 1$ & $17: 1$ & $30: 1$ & $3: 1$ & $2: 1$ & $3: 1$ \\
\hline & \multirow{7}{*}{3} & 1 & $7: 1$ & 59:1 & 110:1 & $7: 1$ & $4: 1$ & $5: 1$ \\
\hline & & 2 & $4: 1$ & $29: 1$ & $35: 1$ & $4: 1$ & $3: 1$ & $5: 1$ \\
\hline & & 3 & $3: 1$ & $23: 1$ & $25: 1$ & $4: 1$ & $3: 1$ & $4: 1$ \\
\hline & & 4 & $3: 1$ & $26: 1$ & $26: 1$ & $4: 1$ & $3: 1$ & $4: 1$ \\
\hline & & 5 & $3: 1$ & $26: 1$ & $27: 1$ & $4: 1$ & $3: 1$ & $3: 1$ \\
\hline & & 6 & $3: 1$ & $20: 1$ & $21: 1$ & $4: 1$ & $3: 1$ & $3: 1$ \\
\hline & & 7 & $3: 1$ & $20: 1$ & $20: 1$ & $3: 1$ & $3: 1$ & $4: 1$ \\
\hline
\end{tabular}

Найвищі числові вирази (6-13:1) співвідношень $\mathrm{Na}^{+}: \mathrm{Ca}^{2+}$ характерні для еякулятів усіх груп бугаїв. Ліміт їх відхилень у групах НКК і СКК - майже однаковий (913:1); у групі ВКК на 3-4 частини вмісту $\mathrm{Na}^{+}$менший (6-9:1). Якщо дисбаланс гомеостазу іонів за нормо- та гіпофункції генеративних тканин статевих органів виражений переміною $\pm 1-3$ частини вмісту $\mathrm{Na}^{+}$, то за гіпофункції зростає до + 9-16.

Об'єктивна оцінка рівноваги вмісту іонів неможлива без детального аналізу іiі стану у системі «клітина - середовище» або між виділеними генеративними тканинами статевих залоз секретами спермальної плазми та сформованими у тканинах яєчок сперматозоїдами (табл. 5).

Значення числового виразу різноіменної пари $\mathrm{Na}^{+}: \mathrm{K}^{+}$спермальної плазми (16:1) і сперматозоїдів (1-4:1) еякулятів дослідних груп 1-3 низькі, але між спермальною 
плазмою та сперматозоїдами (3-15:1) відповідно в 2,5-3,0 та 3,0-3,8 раза більші. Найвищі значення характерні для еякулятів групи НКК (14-15:1), середні - для СКК (5-7:1) і найменші - для ВКК (3:1).

Якщо співставити співвідношення різноіменних пар, визначені у спермальній плазмі та сперматозоїдах еякулятів першої, другої та третьої дослідних групп, із показниками співвідношень між спермальною плазмою та сперматозоїдами, виявляється, що вектор співвідношень $\mathrm{Na}^{+}: \mathrm{K}^{+}$та $\mathrm{Na}^{+}: \mathrm{Ca}^{2+}$ між спермальною плазмою та сперматозоїдами спрямований від високих (14-15:1 і 39-47:1) до середніх (5-7 і 38-42:1) і низьких (3:1 і 25-27:1) значень, але $K^{+}: \mathrm{Ca}^{2+}$ у протилежний бік: від низьких (6-8:1) до середніх (14-17:1) і високих (23-26:1) значень.

При цьому константність співвідношень одноіменних пар між спермальною плазмою та сперматозоїдами в еякулятах усіх груп бугаїв за нормофункції тканин статевих органів виражена на ще вищому рівні, ніж різноіменних у спермальній плазмі та сперматозоїдах. Числові вирази співвідношень $\mathrm{Ca}^{2+}: \mathrm{Ca}^{2+}$ і $\mathrm{Na}^{+}: \mathrm{Na}^{+}$між спермальною плазмою та сперматозоїдами однакові $(4: 1) ; K^{+}: K^{+}-$на $1-2$ частини менші $(2-3: 1)$, а різниця змін залежно від інтенсивності їх гіпо- чи гіперфункції становить лише $\pm 1-$ 3 частини вмісту іонів до визначеної норми.

\section{Висновки}

1. Дестабілізація контроверзно константних рівнів концентрації $K^{+}$спермальної плазми, сперматозоїдів, сперми пов'язана з гіпо- та гіперфункцією яєчок і придаткових залоз статевих органів:

- за гіпофункції їх генеративних тканин спермальна плазма еякулятів групи НКК має однакову концентрацію $\mathrm{Ca}^{2+}$ і $K^{+}$, але вищу $\mathrm{Na}^{+}$; СКК - меншу $\mathrm{Ca}^{2+}$, однакову $\mathrm{K}^{+}$, але вищу $\mathrm{Na}^{+}$; ВКК - меншу $\mathrm{Ca}^{2+}$ і $\mathrm{K}^{+}$, але вищу $\mathrm{Na}^{+}$. Сперматозоїди групи НКК - однакову $\mathrm{Ca}^{2+}$ i $\mathrm{Na}^{+}$, але меншу $\mathrm{K}^{+}$; СКК - однакову $\mathrm{Ca}^{2+}$ і $\mathrm{K}^{+}$, але меншу $\mathrm{Na}^{+}$; ВКК - однакову $\mathrm{Na}^{+}$, але меншу $\mathrm{Ca}^{2+}$ i $\mathrm{K}^{+}$, ніж за нормофункції;

- за гіперфункції спермальна плазма еякулятів групи НКК має меншу концентрацію $\mathrm{Ca}^{2+}, \mathrm{K}^{+}$i $\mathrm{Na}^{+}$; СКК - меншу $\mathrm{K}^{+}$i $\mathrm{Na}^{+}$, але однакову $\mathrm{Ca}^{2+}$; ВКК - меншу $\mathrm{Ca}^{2+}$, вищу $\mathrm{K}^{+}$, але однакову $\mathrm{Na}^{+}$. Сперматозоїди групи НКК - однакову $\mathrm{Ca}^{2+}$ i $\mathrm{Na}^{+}$, але меншу $K^{+}$; СКК - меншу $K^{+}$, але однакову $\mathrm{Ca}^{2+}$ i $\mathrm{Na}^{+}$; ВКК - вищу $\mathrm{Ca}^{2+}$ i $K^{+}$, але меншу $\mathrm{Na}^{+}$, ніж за нормофункції.

2. Вектор співвідношень різноіменних пар, а саме: $\mathrm{Na}^{+}: \mathrm{K}^{+}$у спермальній плазмі, сперматозоїдах, суми концентрацій у спермі та між спермальною плазмою та сперматозоїдами за нормофункції генеративних тканин $\left(0,75-1,38\right.$ млрд./см $\left.{ }^{3}\right)$ спрямований від їх високих значень у групі НКК до середніх у СКК і низьких у ВКК; $\mathrm{K}^{+}: \mathrm{Ca}^{2+}$ відповідно від низьких до середніх і високих; $\mathrm{Na}^{+}: \mathrm{Ca}^{2+}-$ від однаково високих у НКК і СКК до низьких у ВКК.

3. За нормофункції генеративних тканин числові вирази співвідношень різноіменної пари $\mathrm{Na}^{+}: \mathrm{K}^{+}$між спермальною плазмою та сперматозоїдами еякулятів усіх дослідних груп в $3, \mathrm{~K}^{+}: \mathrm{Ca}^{2+}-$ в 3-4, $\mathrm{Na}^{+}: \mathrm{Ca}^{2+}-$ в 4-5 разів більші за сумарні сперми; одноіменних $\mathrm{Ca}^{2+}: \mathrm{Ca}^{2+}$ i $\mathrm{Na}^{+}: \mathrm{Na}^{+}-$однакові у групах, але $\mathrm{K}^{+}: \mathrm{K}^{+}-$на 1-2 частини вмісту менші.

4. Особливості дисбалансу гомеостазу $\mathrm{Ca}^{2+}, \mathrm{K}^{+}$та $\mathrm{Na}^{+}$у спермі за гіпо- $(0,16-$

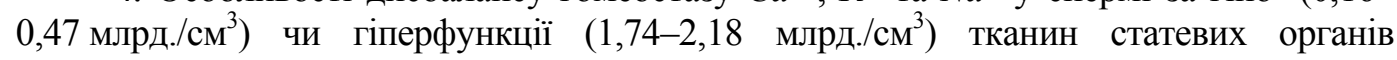
характеризує зменшення $(-)$ або збільшення $(+)$ значень числового виразу співвідношень різно- та одноіменних пар іонів. 
5. Контроверзні концентрації $K^{+}$, константні співвідношення $\mathrm{Ca}^{2+}, \mathrm{K}^{+}$та $\mathrm{Na}^{+}$i дестабілізація їх вмісту у спермальній плазмі, сперматозоїдах і між ними вказують на те, що особливості гомеостазу іонів у спермі запрограмовані на генному рівні.

\section{Бібліографічні посилання}

1. Звєрєва Г. В. Вміст макроелементів і концентрація сперміїв в еякулятах / Г. В. Звєрєва, В. М. Максим'юк // Вісник аграрної науки. - 1997. - № 3. - С. $29-34$.

2. Максим'юк В. М. Кальцій, натрій, калій сперми бугаїв: вміст, розподіл, співвідношення / В. М. Максим’юк, Г. В. Звєрєва // Вісник аграрної науки. - 1997. - № 2. - С. $23-24$.

3. Максим'юк В. М. Іони макроелементів у спермі бугаїв // Науковий вісник національного аграрного університету. Проблеми фізіології і патології відтворення тварин. - К. : 2000. № 22. - С. 156-161.

4. Оцінка впливу умов кріоконсервації на гомеостаз $\mathrm{Ca}^{2+}, \mathrm{K}^{+}, \mathrm{Na}^{+}$у сперматозоїдах і спермальній плазмі / Г. В. Максим’юк та ін. // Клінічна та експериментальна патологія. - 2005. - Т. 4, № 1. - C. 116-120.

5. Патент України на винахід № 95020517, МПК G01N 33/48; опубл. 16. 12. 1997 p.

6. Плохинский Н. А. Биометрия. - М. : Изд-во МГУ, 1970. - 367 с.

7. Технологія одержання сперми і способи оцінки життєздатності сперматозоїдів / УААН та ін.; В. П. Буркат та ін. - Оброшино, 2006. -42 с.

8. Aitken R. J. Sperm function test and fertility // Int. J. Androl. - 2006. - Vol. 29, N 1. - P. 69-75.

9. Aranha I. Concentration of cations in different parts of male reproductive system and their influence on in vitro sperm motility in lizard, Mabuya carinata Schneider / I. Aranha, M. Bhagya, H. N. Yajurvedi // Indian J. Exp. Biol. - 2008. - Vol. 46, N 10. - P. 720-724.

10. Cations and trace elements in the nili-ravi buffalo and crossbred cow bull semen / M. K. Kanwal, N. U. Rehman, N. Ahmad et al. // Int. J. of Agriculture \& Biology. - 2000. - Vol. 12, N 4. - P. 302-305.

11. Cooper T. G. The Sperm Cell. Production, Maturation, Fertilization, Regeneration / T. G. Cooper, C. H. Yeung. - Cambrige, UK : Cambrige University Press, 2006. - 632 p.

12. Gaballero J. Post testicular sperm maturational changes in the bull: Important role of the epididymosomes and prostasomes / J. Gaballero, G. Frenette, R. Sullivan // Veterinary Medicine International. - 2011. - P. 1-13.

13. Increase of human spermatozoa intracellular $\mathrm{Ca}^{2+}$ concentration after fusion with prostasomes / C. A. Palmerini, E. Carlini, A. Nicolucci, G. Arienti // Cell Calcium. - 1999. - Vol. 25, N 4. - P. 291-296.

14. Klein T. The role of potassium chloride cotransporters in murine and human sperm volume regulation / T. Klein, T. G. Cooper, C. H. Yeung // Biol. of Reprod. - 2006. - Vol. 75. - P. 853-858.

15. Saez F. Epididymosomes and prostasomes: Their roles in posttesticular maturation of the sperm cells / F. Saez, G. Frenette, R. Sullivan // J. of Andrology. - 2003. - Vol. 24, N 2. - P. 149-154. 